\title{
GCU
}

Glasgow Caledonian

University

University for the Common Good

\section{Patterns of labour solidarity towards precarious workers and the unemployed in critical times in Greece, Poland and the UK}

Karakioulafi, Christina ; Kanellopoulos, Kostas; Petelczyc, Janina; Montgomery, Tom; Baglioni, Simone

Published in:

Sociological Research Online

DOI:

$10.1177 / 1360780420980464$

Publication date:

2021

Document Version

Author accepted manuscript

Link to publication in ResearchOnline

Citation for published version (Harvard):

Karakioulafi, C, Kanellopoulos, K, Petelczyc, J, Montgomery, T \& Baglioni, S 2021, 'Patterns of labour solidarity towards precarious workers and the unemployed in critical times in Greece, Poland and the UK', Sociological Research Online, vol. 26, no. 3, pp. 739-758. https://doi.org/10.1177/1360780420980464

\section{General rights}

Copyright and moral rights for the publications made accessible in the public portal are retained by the authors and/or other copyright owners and it is a condition of accessing publications that users recognise and abide by the legal requirements associated with these rights.

Take down policy

If you believe that this document breaches copyright please view our takedown policy at https://edshare.gcu.ac.uk/id/eprint/5179 for details of how to contact us. 


\title{
Patterns of labour solidarity towards precarious workers and the unemployed in critical times in Greece, Poland and the UK
}

\begin{abstract}
The purpose of this article is to examine whether and by what means traditional unions and other labour-oriented organisations engage in solidarity activities in favour of precarious workers and the unemployed. Our findings derive from qualitative data analysed from 10 in-depth interviews per country conducted as part of a large collaborative project with participants sampled from trade unions and other labour-oriented solidarity organisations based in three European national contexts: Greece, Poland and the UK. Our aim here is to discern common features and differences in the strategies and answers given, within the three national contexts To this end we examine: the actors engaged in labour solidarity; the value frames upon which these actions draw; the beneficiaries of their solidarity actions; the type of activities adopted mainly in favour of precarious workers and the unemployed; and their engagement in transnational labour solidarity activities.
\end{abstract}

Keywords: unions - labour organisations - solidarity- precarious workers unemployed

\section{Introduction}

In previous decades there has been an ongoing debate regarding the crisis facing trade unions that is taking place in a context where they are confronting multiple challenges, such as globalisation, anti-labour/neoliberal and more recently - austerity policies, alongside a long-term decline of union density and the consequent reduction of their bargaining power.

Moreover, research has scrutinised the ability of traditional unions to generate solidarity activism and to advance the interests of precarious workers and the unemployed, thereby embracing the most vulnerable segments of the workforce. In terms of precarious workers, despite an initial tactic of exclusion, over time, 'organising the unorganised' became a central tenet of the strategic responses of trade unions to economic and political challenges (Heery, 2005; Martinez-Lucio et al, 2017). Nevertheless, organising the unorganised often remained a technical issue (Hyman, 2007) rather than being a more integrated and radical rethinking of union objectives (Simms and Holgate, 2010). Similar concerns have also been expressed regarding the relationship between unions and the unemployed, which is even more problematic. Despite their concern for the unemployed, the focus of unions on safeguarding employment has often resulted in the concerns of the unemployed being relegated (Chabanet and Faniel, 2012), while in other cases unions have not dedicated the necessary resources to organise them (Faniel, 2012).

The critique of traditional unions' capacity to act effectively coincides with the emergence of other labour-oriented groups and organisations who also claim to advance the interests of precarious workers and the unemployed and who engage, alongside (or sometimes even against) traditional unions through labour solidarity activities. Very often, traditional unions, have been characterised as more bureaucratic 
and having formal decision-making structures and procedures, in contrast to more spontaneous, participatory, decentralised and activist-led models of organisation, which can be considered more effective in enhancing labour solidarity (Hyman and Gumbrell-McCormick, 2017).

The purpose of this article is to examine whether and by what means traditional unions and other labour-oriented organisations engage in solidarity activities in favour of precarious workers and the unemployed in Western countries.

In this paper, (labour) solidarity: i) corresponds to an attitude or behaviour of support of others in need that is linked to shared norms, rights and obligations; ii) can be, either tied to abstract communities and thus associated with a universal understanding of generalised support or associated with particular needs and groups, or even be considered as a condition for group membership, mutual contributions and/or exchange relations. ${ }^{1}$

Our findings are derived from qualitative data analysed from 10 in-depth interviews per country conducted as part of the transnational research project TransSOL (Transnational Solidarity at Times of Crisis), with participants sampled from trade unions and other labour-oriented solidarity organisations in Greece, Poland and the UK.

Furthermore, given the focus of our study on transnational solidarity we were also interested in capturing activities developed across national boundaries. We therefore included in our sample those organisations which pursue - according to their objectives or mission statements, labour solidarity beyond and across national borders and which claim to pursue a transnational "agenda" and/or engagement in transnational activities. $^{2}$

The three countries examined represent diverse cases in terms of institutional settings, industrial and employment relations traditions, trade union practices and labour market regulation. Despite the diverse contexts, unions and labour-oriented organisations in the three cases had to confront: i) major economic and political challenges: on-going neoliberal reforms in the UK, austerity policies in Greece, and the transition from socialism to capitalism and accelerated liberal labour market reforms in Poland; ii) labour market specific challenges including the growth of precarious employment and rising unemployment.

A key aim of our study has been to uncover labour solidarity activities in support of precarious workers and the unemployed, across the three national contexts, in order to discern common features and differences in the strategies and responses. To this end we examine: the actors engaged in labour solidarity; the value frames upon which these actions draw; the beneficiaries of their solidarity actions; the type of activities adopted in favour of precarious workers and the unemployed; and their engagement in transnational labour solidarity activities.

\section{Unions confronting the challenge of precarious work and unemployment in Greece, Poland and the UK: setting the context}

In order to understand the patterns of labour solidarity in favour of precarious workers and the unemployed in the three national contexts, we will briefly demonstrate some features relating to the strategies adopted by traditional actors of labour solidarity and by 'new actors' intervening in the field of labour solidarity in recent years. 
Regarding Greece, the onset of the 2008 crisis generated discussions on the 'rigidities' of labour market regulation. The employment relations system has thus been targeted as a priority area for reform, resulting in its gradual dismantling and deregulation. Consequently, precarious employment and unemployment increased, while employment protection declined.

In this context, traditional industrial relations actors were impacted. For several years, unions have been experiencing a structural and representation crisis. Nevertheless, despite declining union density (from $27.5 \%$ in 1998 to $20.2 \%$ in $2016^{3}$ ), organising non-unionised workers remained a low-priority issue for official unions (Kretsos and Vogiatzoglou, 2015), which have often adopted an attitude of exclusion towards precarious workers. Trying to overcome the above tendencies, some segments of the labour movement founded in 1999 the All-Workers Militant Front (PAME), that opposes the two official union confederations: the General Confederation of Greek Workers (GSEE) and the Civil Servants' Confederation (ADEDY), both being considered by PAME to pursue a more consensual, governmental and capital-friendly trade unionism. Without being formally linked to the Greek Communist Party (KKE), PAME mainly coordinates unions controlled by KKE members and leaders (Tsakatika and Eleftheriou 2013), and its foundation is considered as being important for maintaining class traditions within the labour movement (Bithymitris and Kotsonopoulos, 2018). ${ }^{4}$

Meanwhile, from the late 1990s collective action by precarious workers in sectors where flexible work predominated, has been mobilised (e.g. Primary Unions' Coordination Syntonismos Protovathmion Somation). These unions feature a left-wing or anarchist-oriented orientation, accompanied by strong rank-and-file activism, while they choose to articulate their work-related claims within a more general context of working-class struggles (Mattoni and Vogiatzoglou 2014). The Coordination has managed to unionise precarious workers while opposing both the 'governmental' syndicalism of GSEE and ADEDY and the partisan-controlled unionism of PAME.

Even if the 2008 crisis could constitute the opportunity for unions to renew themselves and turn their attention towards precarious workers and the unemployed, this has not been the case (Kretsos and Vogiatzogou, 2015). Despite intense strike action, mainly during the first years of the 2008 crisis, and momentary explosions of class consciousness during strike activity, traditional top-level unions have remained guardians of vested interests (Karakioulafi, 2019). However, new precarious workers and unemployment unions and initiatives have emerged (e.g. Workers' Clubs, the worker-managed factory Vio.Me, and informal precarious workers collectivities such as Generation 400). Nevertheless, they are facing their own difficulties, relating to their capacity to intervene effectively in sectors with high unemployment rates as well as challenges in scaling up their activities in the context of limited resources (Vogiatzoglou, 2014).

Compared to other EU member states Poland is a country almost unaffected by the 2008 crisis. Despite a positive economic environment, the Polish government accelerated liberal labour market reforms and the de facto inexistent 'crisis' was frequently evoked as a justification for further liberal reforms. Changes in the labour market implemented by the government between 2007 and 2015 tended to increase flexibility and were more favourable to employers than to workers. Consequently, the Polish labour market is becoming increasingly more precarious and segmented through a range of employment contracts that have dramatically jeopardised workers' 
rights and entitlements. In fact, a new set of employment contracts have been created outside labour law to fall within the jurisdiction of the civil code ( "junk contracts") that include umowy zlecenie (civil contracts) and umowy o dzieto (contracts for specific work), where, workers can be deprived of some or all of the basic entitlements of employment (including pension and health insurance, paid leave, or a notice period).

These developments became problematic for unions, which were already facing a membership crisis. Poland, considered as a 'transitional' or 'mixed' model regime of industrial relations, combining low union density and authority as well as low (3040\%) collective bargaining coverage (Visser, 2008). Polish unions have experienced a massive decline in membership, that fell from 22\% in 1990 to 5\% in 2017 (as a percentage of the total adult population) and from $36 \%$ to $11 \%$ of the employed persons.

Nevertheless, Shin and Yla-Antilla (2017) have shown that in 'transitional' countries, such as Poland, industrial relations regimes are more open to 'new social risk groups' and that by renewing their strategies unions could mitigate what seems like a neverending crisis. Hence, although Polish unions still concentrate mostly on permanent employed workers' rights they are increasingly opening-up to new categories of employees, by introducing action programmes or strengthening their position in workplaces (Mrozowicki and Trawińska, 2012). In 1999, the OPZZ (All Polish Federation of Trade Unions) created Konfederacja Pracy (Confederation of Labour, $\mathrm{KP}$ ) with the main goal to organise and defend precarious employees in the private sector, especially those working in hypermarkets (Krzywdziński, 2012). In 2001 a new, independent, grassroots union has been created, Inicjatywa Pracownicza (Workers' Initiative, IP), which has a similar objective of defending the rights of precarious and vulnerable workers. IP was created in opposition to 'traditional' unions, in order to address the interests and needs of the most vulnerable segments of the workforce (i.e. migrants, ethnic minorities, and women) (Petelczyc and Matuszczyk 2019). Moreover, "Solidarity" Union, in collaboration with other confederations provides support and organises campaigns to defend workers' rights in the 'special economic zones' (areas where labour rights can be easily violated) (Krzywdziński, 2012). In recent years, a major achievement of unions on these issues has been the implementation in 2018 of a decision of the Constitutional Court, allowing workers employed under flexible, task-based civil law contracts to form and join unions. A regulation that provided precarious workers with new rights and enabled them to benefit from protection previously reserved to union members on standard employment contracts.

Consequently, Polish unions' activism in support of precarious workers consists mainly in grassroots activities and interventions aiming to influence legislation in favour of those employed through non-standard employment contracts.

In the UK, the 2008 crisis inevitably provoked a response from policymakers. As in other contexts the reality of market failure was rapidly repackaged into a narrative of excessive public spending. Consequently, the period following the 2008 crisis, particularly when the Conservative led Coalition Government came to power in 2010, was marked by austerity measures that were particularly focused on public spending more broadly and welfare spending specifically. Unions, particularly those in the public sector, mobilised broad campaigns against austerity policies and sought to raise awareness of their impact. However, as in other contexts, they were simultaneously 
dealing with a transforming labour market and a decrease in union density best understood against an historical backdrop of the 1980s when unions confronted the Thatcher Government's programme of privatisation and the closure of key sites of heavy industry (Milne, 2004). The latest figures available reveal that there has been a steady decline in union membership ever since, from 13 million union members in 1979, to 6.2 million members today (Department for Business, Energy and Industrial Strategy, 2018), although with a small upward trend very recently.

One issue that has encapsulated the challenges faced by unions in the UK has been the Trade Union Act 2016. Although a less draconian piece of legislation than the Bill that preceded it, the Trade Union Act meant that from 1st March 2017, unions in the UK have witnessed increased regulations of their forms of action. Of course, these obstacles created by new legislation need to be placed in the context of other challenges facing the unions in the UK, namely the transformations in the labour market, particularly the shift from standard to non-standard employment relationships.

As precarious employment has grown, unions in the UK have felt it necessary to take new forms of action with a constituency of workers whose occupational identity is made more fluid by the insecurity of their contracts. This has been demonstrated by initiatives such as those undertaken by the Unite trade union which has on the one hand launched a new form of 'Community' membership to encompass those who are unemployed and other groups experiencing marginalisation ${ }^{5}$ while on the other hand mobilising a high-profile campaign in support of casual agency staff working for the retail giant Sports Direct which contributed to the firm being investigated by a House of Commons Committee regarding its employment practices. ${ }^{6}$ Another example of increased activism in tackling precarious work has been evident in the hospitality sector where direct action by the Better Than Zero movement (including the picketing of restaurants that employ staff on zero-hours contracts) has led to some successes with employers but also a raising of awareness, particularly among young workers, of the role of trade unions. ${ }^{7}$ These developments point towards a realisation among the unions of a gap between traditional models of unionism in the UK and the needs of precarious workers and the unemployed. When we explore our empirical findings from the UK later in this paper, we shall observe that other organisations have also stepped forward to bridge this gap. However, understanding our findings from the UK requires not only an awareness of contemporary challenges in terms of non-standard forms of employment but also an appreciation of the national institutional context in the specific field of labour and industrial relations. Thus our analysis of the UK should be perceived through the prism of the liberal market economy (Hall and Soskice, 2001) context where a culture of social dialogue is not well developed in various sectors and bargaining between workers and employers is often conducted at the level of the firm rather than the sector.

Therefore, although the challenges faced by unions in the UK are similar to those found in other contexts of our study, namely Poland and Greece, there is some evidence of a growing motivation among unions to meet these challenges through legislation and by remaining versatile enough to encompass the needs of a new generation of workers for whom the experience of precarious work is a new normal.

Hence, the scenarios we have illustrated in this section show that despite significant differences in their economic configuration, and in particular a different trajectory in terms of the impact of the 2008 crisis, Greece, Poland and the UK share: i) a common trend of flexibilisation and deregulation of employment which has for some time been 
an agenda of the neoliberal economic and employment policies in Europe and beyond, an agenda which has exacerbated the chasm between those workers who are 'in' well protected and regulated employment and those who are 'out'; ii) such flexibilisation and deregulation patterns have been largely imposed to disempower unions (falling unionisation rates have been a common trajectory of unions in the three countries); iii) the general effort of unions to focus their protection on those 'in' while limiting actions for those 'out' to episodic and specific opportunities.

In such a scenario how has solidarity with precarious workers and unemployed been developed among the labour movement? We explore this issue in the next section.

\section{Patterns of labour solidarity across Greece, Poland and the UK}

This paper is based on 30 in-depth interviews conducted across the three countries (10 in each ${ }^{8}$ ). Our purposive sample sought to capture the heterogeneity of the labour movement across our three countries. Therefore, our sample includes traditional unions, labour-oriented organisations, social movements, protest-oriented groups, self-managed organisations, NGOs and informal/non-professional groups. As outlined earlier in this paper, a key dimension to the sampling strategy of the research project was to include those organisations that were also engaging in activism beyond their own national borders. Thus, our sample encompasses organisations claiming to have either a transnational 'agenda', or to engage in transnational activities.

As to the selection criteria of inclusion for respondents within the selected organisations, and according to the project's guidelines, only one person should be interviewed for each organisation, and interviewees should be participants, active members, activists, volunteers (not leader-functionaries with pure office jobs, not beneficiaries), able to answer the questions about concrete practices and activities. Each of our interviewees provided informed consent to participate in the study and to have the interviews recorded which we then anonymised.

With respect to the content of interviews, the questionnaire addressed a number of topics (organisational aspects, solidarity activities, innovative practices, cooperation with institutional actors, outcomes etc.) but here we focused our analysis on two sets of questions. A first set of questions concerned the target groups and beneficiaries of their action. The aim was to uncover whether unemployed and/or precarious workers are among their beneficiaries and to what extent they are in solidarity with them. A second set of questions related to their understanding of solidarity (e.g. definitions, helpfulness for target groups, limitations).

\subsection{Perceptions of workers' solidarity, target groups and solidarity actions}

In Greece, the sample included mainly protest-oriented groups and most particularly rank-and-file unions and other grassroots labour groups. Five of the organisations we interviewed were informal organisations, while the other five employed a more formal organisational structure. At the organisational level, nine out of ten organisations are small groups without paid staff and fully controlled by general assemblies. Most were only created a few years before the eruption of the 2008 crisis and represent a bottomup reaction to the perceived inefficacy of official unionism in having done very little to defend workers' rights, failing to include unemployed and precarious workers in their ranks, and being bureaucratised.

"...the structures of solidarity for unemployed and precarious workers is what is needed but this must not be done separately...it has to be done from inside the unions." (Unemp3, 09/2016). 
Regarding their motivations, most of our interviewees appear to share strong workingclass identification. They participate in their groups not only to protect and advance sectoral and professional interests, but also to advance the causes of the entire working class, meaning workers in permanent or precarious employment conditions, unemployed and immigrant workers.

Thus, besides the employed, unions in our sample are specifically trying to represent the growing number of unemployed and defend their rights. In some of the unions, the unemployed are also embraced as union members and benefit from the union's actions.

"The unemployed of our sector are rightfully members of our union, the same goes for those part-time or in other "flexible" forms... [even] if one of us gets fired he remains a member of the union." (Unemp2, 09/2016).

They also advance the rights of immigrants, most of them being precarious workers and weakly unionised.

"We accept immigrants in our union...the issues of unemployment and precarity do not have a national identity, they have a class identity." (Unemp7, 09/2016).

Respondents appear to share a more universalistic understanding of solidarity, that is comprehended as generalised support and not restricted to any specific group of workers or conditionality.

"[We] aim at the world of labour...unemployed of course but also immigrants as potential precarious workers and even those who are been trained now to become future workers." (Unemp1, 09/2016).

Besides their political orientation focusing on (working) class interests, this perception derives also from the fact that employment precariousness affects an increasing number of working people.

“At this moment we are all precarious workers.” (Unemp9, 09/2016).

Two of the interviewed representatives do not perceive labour solidarity only in terms of support towards precarious workers and the unemployed but rather as a 'common struggle' of working-class people (Unemp 2 and 5, 09/2016).

Some of these organisations initiate innovative actions, such as: the issuing of unemployment cards to all the union members in order to obtain discounts in public transportation, insurance coverage to the self-employed, induction of precarious workers into public sector unions, on-the-spot surveillance of employers to ensure they do not hire workers without insurance, organisation of campaigns to boycott certain shops or companies products, neighbourhood level activities, the set-up of mutual aid or solidarity funds for the unemployed, and free medical care.

Bottom-up labour mobilisation, and direct democracy are among the practices most of our Greek interviewees promote and consider as innovative. The workers of one of the organisations in our sample who occupied and self-managed their factory that was facing closure, implemented in practice the above principles: self-managing the factory, not employing any hierarchical structure, and distributing and selling their products through social movement channels and not through the market.

In Poland, unions and other labour organisations reacted differently to labour market transformations and didn't seem to share a common understating of solidarity. Most 
often they perceived solidarity in terms of cooperation or in relation to the target groups they supported. However, almost all respondents, regardless of the type of organisation, stated that they had broadened the constituency where they targeted their actions.

Polish unions, as revealed above, are not exceptional from general European or Western tendencies: traditionally focusing on 'insiders', they gradually recognised the need to also represent more marginalised groups. Thus, they engaged in activities in support of precarious workers (i.e. persons employed under civil law contracts), the working-poor and working students:

"We respond to all the changes connected to flexibilisation and precarisation. For us, every person selling their labour force is a worker." (Unemp7, 06/2016).

Our respondents emphasised that due to labour market transformations, they had to adjust and broaden their activity to new target-groups, such as the unemployed not traditionally represented by unions (particularly younger unemployed people), women, those in poverty or those in need due to their exclusion from the labour market:

"In our union, we stand for the unemployed who can become our members when they need help. Especially since it is such a situation in Poland that the unemployed are often excluded." (Unemp8, 09/2016).

Three organisations' representatives drew attention to the extreme difficulties younger people were facing in the labour market which led to their organisation targeting action in support of this group. Such was the demand for this type of support one organisation was created in order to support younger workers. Another organisation's representative called our attention to the fact that the crisis in Western Europe had reduced the motivation for young Poles to migrate to the West.

Union activism of course often extends beyond employment issues. One of our respondents emphasised that his union also worked to protect the rights of people whose problems are not directly related to employment issues, collaborating with social movements (i.e. those threatened with eviction, women's movements for legal abortion). This expansion of target-groups is related to an engagement in a broader politically oriented struggle that surpasses labour market issues.

"One can say that our trade union has twofold goals. On the one hand, the current struggle for improvement of working conditions and pay, on the other hand a broader, long-term social change, towards a society more based on the ideals of self-governance, workers' control over the production process, democracy and direct democracy." (Unemp8, 09/2016).

Other labour organisations have also broadened their scope of beneficiaries. In fact, they not only provide support and services towards the unemployed or other vulnerable groups, but also to other organisations (NGOs) and institutions (public and private) that are active in the field of employment. In this sense their beneficiaries include:

“Everybody who has any relation to the labour market.” (Unemp5, 06/2016).

These organisations also highlighted the role of what they called 'social innovators', including volunteers and social leaders helping them in tackling unemployment. 
Almost all respondents, regardless of whether they represented unions or other organisations, considered their organisation as being innovative and using new methods of intervention. Therefore, their actions are not limited to demonstrations. They also make use of other means pressure and opposition, often related to broader political issues (i.e. against CETA, TTIP, the extreme right, etc.).

"We use for example a consumer boycott to put pressure on employers." (Unemp8, 09/2016).

Other organisations focus on new methods and fields of intervention in order to adjust to the changing environment, such as training or organising meetings with entrepreneurs:

"We try to look for methods of work that primarily improve efficiency but can also be interesting for people. We were one of the first to, for example, publish educational board games (...) we are now running a social economy support centre, we are not only trying to teach and advise but there is also some kind of attraction, the way in which meetings are organised, the way that our publications are made and presented should be something fresh to surprise the audience." (Unemp3, 05/2016).

In the UK, the solidarity efforts we discovered emanated from various groups. Although unions and labour organisations are engaged in a range of solidarity activities, they still retain the key role of servicing members through basic employment issues such as health and safety at work. One union official explained that a focus of recent campaign efforts has been to ensure the safety of retail workers in their workplace from abusive behaviour by employers or the general public. She added that the constitutional arrangements in the UK meant that her union ensured that new laws applied to both central and devolved levels of government:

"It's about the right to work in safety and with respect and that's not always safety and respect from your employer, that's from the general public...our union argues that we can only address this problem if we legislate and we've got a Bill drafted for both the UK Parliament and the Scottish Parliament." (Unemp6, 09/16).

Another union organiser explained that his role was specifically to expand the work of the union beyond the usual base and into those communities on the frontline of precarious work, unemployment, and inequality. He explained that even though constitutional issues were often dominating the headlines, the reality on the ground was that in order to tackle issues collectively and bring the community together, there was a need for proactive organising by union activists like him:

"Precarious work is still going on, austerity is still going on... something we've been talking about within the union is having to step it up in terms of our connections, our organisation with migrant workers and agency workers. Because we've left the EU, there is that horrible immigration conversation really starting to take surface and it's almost like a green light for it to be out in the open...we know if you organise within a workplace and you have Polish shop stewards, it really starts to break away those barriers and workplaces actually start to stick together." (Unemp7, 08/16).

This focus on communities was echoed by another union official based in London who was emphatic that the impact of the austerity measures had been most acute in some of the poorest communities across the UK whom his union members served in 
the public sector. He added that alongside the redundancies that his members had suffered had come a shift in their roles to be responsive to the urgent needs of vulnerable people in disadvantaged communities.

"If there are plans to cut jobs, that's going to impact upon what we can do in communities and by definition the people who need us tend to be the most vulnerable anyway, the elderly, disable people and the poorer sections of our communities...but one of their [the UK Government] big problems is that they don't like an effective service that has a very unionised workforce." (Unemp2, 10/16).

Another union official, also based in London and representing workers in the creative sector explained that in recent years the union had become conscious of a need to widen its scope of appeal and better reflect issues that were being raised in wider society. As such the union had been refocusing its campaigning more recently on issues of gender balance, and targeting recruitment on groups who were underrepresented, specifically from the LGBTQ + community and from BAME ${ }^{9}$ communities:

"The top priority for us over the next few years is engaging many more members and potential members from non-traditional backgrounds. We've had a real problem over the years of being perceived and composed of white men in our union even though we're 50/50 in our union male and female, so our current general secretary has undertaken a lot of work to reach out." (Unemp1, 09/16).

Of course, not all organisations in our sample were unions; some were located in the third sector and thus engaged with a variety of different target-groups. This was evident in Wales where one organisation was offering support to young people in search of employment on the one hand, whilst on the other hand working to enable the better integration of migrant families in the community. This broad-spectrum approach towards target groups was mirrored in our findings from interviews with other third sector organisations including one in the west of Scotland. They had strong connections to the union movement and had engaged with union members and nonunionised workers experiencing low pay while delivering English classes for workers from Eastern Europe and programmes of support to newly arrived refugees. Echoing sentiments expressed by other interviewees about bringing people together, she explained that her organisation targeted support to:

"The hardest to reach, the lowest paid and the lowest skilled... in Glasgow we're doing masses of work with refugees and asylum seekers...not just language classes but we've developed what we call language cafés because we realised it was not just about language, it's about giving people the opportunity to talk." (Unemp9, 10/16).

The modes of partnership and collective action engaged in by our interviewees often reflected their organisational model. For example, among unions there was a clear propensity to conceptualise working in partnership as working with other unions in different sectors. In terms of the interviewees from organisations other than unions again their spectrum of partnerships appeared broader and more reflective of the variety of groups whom their organisations were supporting. For one NGO the existence of various groups, although welcome, represented a challenge for coordination efforts. For another NGO, there was an emphasis on the benefits of the 
heterogeneity of the various community groups and networks with whom they engaged alongside a long-standing relationship it had with the trade union movement across the UK. For some NGOs we spoke to, partnerships with academics and universities was commonplace and was a source not only of research into their specialised fields but also of potential funding from combined efforts on research projects.

Hence, despite the disempowerment of unions and the weakening of employment rights and consequently the lost socio-economic centrality of unions and workers, the neoliberal policy environment has not fully prevented unions and the social actors pushing from 'below' to develop solidarity attitudes and actions. These efforts focus on improving conditions for those workers with fewer rights and the unemployed, the very groups that have been paying the highest price for the transformation of the economy and society in the early $21^{\text {st }}$ century.

\subsection{Workers' solidarity in midst crisis}

As to the consequences of the 2008 crisis on organising precarious workers and the unemployed, in the Greek case almost all our interviewees underlined the ambivalent effects of the 2008 crisis on unions' attitudes towards workers.

On the one hand, a direct effect of the 2008 crisis on unionism is that the closure of many companies also meant the disappearance of the unions that operated within them.

"When an old enterprise closes and a new one starts that also means that unionism in the new enterprise has to start from the beginning and under worse conditions since new employees are afraid to get unionised for fear of losing their jobs." (Unemp2, 09/2016).

A number of interviewees said that during the crisis, union membership was reduced and many of the remaining members became inactive.

On the other hand, interviewees referred to the positive effect the 2008 crisis has had on raising workers' awareness and consciousness, and on solidarity among the employed and unemployed given that the economic strain and deteriorating working and living conditions are common to both groups. Even among the unions that lost members, this cognitive effect is regarded as important.

"The crisis helped us to understand and realise our power and how much this power can be strengthened through forms of cooperation and solidarity." (Unemp5, 09/2016).

Another union representative considered that the crisis has had a positive effect on workers' attitudes towards self-organising in order to achieve better labour conditions.

"With the crisis it becomes clearer to the people that only through their selforganisation could they achieve things since legislation is becoming all the more flexible and against workers." (Unemp3, 09/2016).

In the Polish case, many of our interviewees did not perceive the 2008 crisis as having an impact on their work. Nevertheless, most adopted new modes of action, expanded their activity towards new target-groups and redefined how solidarity was operationalised. Respondents attributed these changes either to the transition from a socialist to a capitalist economy or to the emergence of critical voices contesting the neoliberal vision of the economy. 
One respondent connected the growing mobilisation (demonstrations, national days of protest) during the period between 2011 and 2013 with the opposition to neoliberalism and its role in the 2008 global financial crisis. From his perspective, the sense of solidarity had increased particularly among middle-class workers (i.e. artists, administrative and NGO workers).

Another interviewee understood this process somewhat differently explaining that rather than 2008 crisis, it was the transformation to capitalism that has caused numerous problems, such as growing inequalities, decreasing solidarity and a rising social callousness. According to him, solidarity had transformed into being:

"Middle-class employed in the office that criticises all and does not identify with any social or professional group.” (Unemp7, 06/2016).

One representative linked the decline in solidarity to discourses surrounding the 2008 crisis and the so-called, perceived, migration crisis:

"Those crises are linked. The extreme right redirects the crisis into xenophobia. All that the economic crisis changed positively in the economy (e.g. new, non-neoliberal fiscal policies) and the rise in solidarity is now being lost. Solidarity is decreasing and limited only to ethnic boundaries. From our perspective, it is a disaster, because it literally replays the '30s." (Unemp8, 09/2016).

In the case of the UK, interviewees consistently connected the 2008 crisis with the austerity measures introduced by government and the impact on communities.

For one union official from a large cross-sectoral union, the period of the 2008 crisis had also triggered something of a change in the backgrounds of some of the activists, with a shift away from left-wing students to more working-class voices being represented. The role of new voices also reflected by another trade union official who explained that since the 2008 crisis her union had placed greater emphasis on the issue of low-paid work and unpaid traineeships, adding that the catalyst had been:

"A groundswell from our membership. Initially from young members who were coming out of college ...we got together a group of members and came up with some policy ideas and actually we then committed resources through employing a specific staff member and launching a massive campaign about two years ago basically to start organising in a much more structured way. " (Unemp1, 09/16).

Our interviews revealed that the 2008 crisis was also being perceived by some labour organisations as a dynamic for accelerating issues of insecure work:

"We have seen significant reductions in public funding and significant numbers of job losses, with redundancies and early retirements, that's always been a bit of an issue but certainly it's been accelerated over the last five or six years...but also, there has been a growth in more precarious forms of employment." (Unemp10, 11/16).

For others, another feature of the period of crisis had been increasing xenophobia and diminishing solidarity with migrants and refugees:

"The emphasis has changed I would think over the last decade from one of real support to a stage of 'they're taking our jobs'...this seems to be the more generalised and determined response." (Unemp5, 09/16). 
Thus, overall, across our three countries, the 2008 crisis has produced a mixed outcome in terms of solidarity and unionism. On the one hand unions have been further disempowered as a result of increasing unemployment and underemployment. On the other hand, the 2008 crisis has contributed towards refining the unions understanding of the neoliberal policy threads that are common across borders and that imposed, as a single crisis solution, an austerity paradigm, which has had negative consequences on unions and workers.

\subsection{Transnational labour solidarity}

Alongside unions' solidarity concerning precarious workers and the unemployed, we were interested in scrutinising any form or attitude of solidarity among unions which transcends national boundaries. In fact, although unionism has always been a transnational phenomenon, the 2008 financial crisis and the neoliberal policies have often pushed unions and workers to focus narrowly on their immediate spatial proximity. How far is that the case for Greece, Poland and the UK?

Regarding transnational labour solidarity, in the Greek case, most of our interviewees hold, generally, labour internationalism as a core value and that solidarity has neither borders nor is it possible to operate by excluding people from other ethnic groups.

"Obviously, such struggles do not know or ought to know frontiers. [...] the solidarity of workers and the unemployed across the globe, class solidarity, should be at the top of our priorities." (Unemp8, 09/2016).

Nevertheless, at the practical level, most of the organisations we interviewed do not participate on a regular basis in any international networks and only a few share some occasional and less-institutionalised relationships with unions in other countries. Additionally, two of the unions reported that they never had any transnational interlinkages, while another two have the most frequent transnational interlinkages. For those having connections with labour organisations and unions abroad, these relationships derive mainly from their common political orientation: thus they have contacts to radical, anarcho-syndicalist unions, labour groups or initiatives (such as self-managed factories) and this mainly takes the form of contacts and information exchange and to a lesser extent common actions and campaigns. As a union representative stated, their contact with unions abroad (even though it was infrequent), is important, because it helps one to realise how common some problems are from one country to another, as well as the necessity of transnational action.

In Poland, as solidarity is most often understood in terms of 'people we are supporting', the scope of activity varies and evolves from regional and local level towards the national and international scale.

Some organisations, such as NGOs working in the field of (un)employment limited their activity to the local and regional level.

“For us, the local community is the most important." (Unemp4, 05/2016).

Other organisations conceptualised solidarity in a way that extended beyond national boundaries. One of the unions we interviewed perceived solidarity as neither national nor transnational, but as a class value, which is not so common in Poland:

"Solidarity of all workers, regardless of industry, position, type of contract, gender, nationality and country. It is solidarity beyond borders, intercompanies. It manifests itself in maintaining contacts with organisations in other countries to mobilise and support each other (...) If solidarity is defined 
by social class, we are not in solidarity with those who are on the side of capital. (...) This division, however, is not simple and is always defined in practice." (Unemp8, 09/2016),

Some of the unions we interviewed engaged in solidarity actions with workers in other countries: either by providing support to the establishment of Polish workers' unions in other countries and organising training programmes on their labour rights; or by engaging in solidarity actions towards non-Polish workers in other national contexts. During the 2008 crisis, respondents noticed the existence of a growing solidarity with the unemployed and vulnerable groups, especially in Greece and Spain.

Moreover, national level organisations engaged in solidarity activism, regardless of their beneficiaries' nationality. The All-Poland Alliance of Trade Unions, in light of the continued violation of the labour rights of Ukrainian workers in Poland, has established a special section in order to protect the labour rights and interests of migrant workers (also open to workers from other countries, e.g. from Russia, Belarus or Moldova).

"We are in solidarity with all the people in the Polish labour market, regardless of their nationality." (Unemp8, 09/2016).

In the UK, across many of the interviews with union officials and organisers it became clear that national and sub-national platforms, such as the Trades Union Congress and the Scottish Trades Union Congress were instrumental in offering a common arena around which trade unionists from various sectors could coalesce. This meant that not only would unions have delegates whom they would send to contribute towards developing the policy positions of these broader platforms but in some cases the unions of our interviewees had members who would serve on the executive committees of these cross-union bodies. This experience was replicated for some interviewees at the European level where their unions would have representation in the pan-European union federations whose work would focus on protecting the interests of workers in policymaking processes taking place in the EU institutions and other international policymaking fora. For some interviewees, this explicitly involved forms of transnational solidarity that were directed at those workers who were perceived to be at the frontline of austerity measures:

"In terms of solidarity in the context of Europe, for a while the ETUC work and our work on the issue of Greece was probably the most significant given the attacks on living conditions there and so we focused heavily on Greece for a while. In particular we were part of a mission that went out, our President went out there and there were various activities and protests undertaken." (Unemp10, 11/16).

Despite the context of Brexit and the uncertainty it was creating across different sectors and indeed society more broadly, one trade union official in London whom we interviewed was confident that although the UK was poised to leave the European Union these bonds of solidarity were likely to continue across the continent:

"I don't think there is any reason why that will end, despite Brexit, because we have a lot of non-EU countries that are part of that." (Unemp2, 10/16).

Another organisation we interviewed, this time a feminist NGO, had a broader scope of action which targeted support towards women working in the garment and horticultural industries in East Africa, South Asia and Central America, often with a 
focus on those women who are non-unionised. Therefore, the focus of support of the organisations we interviewed reflected a broad range of vulnerable groups not only in the UK but building connections transnationally.

"We've been working with women internationally who work in UK supply chains and we work with local partners, sometimes they're trade unions, sometimes they're women's groups to provide support, education and training to help them be aware of their rights as workers and to negotiate for their rights with their employers." (Unemp4, 09/16).

Thus, our study shows that unions in Greece, Poland and the UK value the importance of transnational solidarity, often also as a means to counter the difficult political and economic environment they met at the national level. Nevertheless, sometimes transnational solidarity remains important only from a rhetorical point of view and does not always imply concrete actions or permanent synergies.

\section{Conclusions}

Our three countries represent undoubtedly diverse cases in terms of institutional settings and industrial relations traditions. Nevertheless, they have all been impacted by changes in the global political economy and particular trends, such as the diffusion of atypical forms of work and related contractual arrangements, the weakening of workers' rights and entitlements, and the further segmentation of labour markets, in which the new insecure and less well paid jobs have gone to young people, women, and migrants. Against this background, in each of our countries, unions which have experienced a long decline in terms of membership and leverage over government policy, have tried to diversify their portfolio of interests and their constituencies. In a nutshell: they have broadened their focus of action from 'insiders' to 'outsiders'. In our countries, however, such a shift of focus by unions has been fostered by the development of new organisations and grassroots movements that have vocally advocated for the rights and entitlements of the 'new' workers, and that have, therefore, challenged traditional forms of workers' representation.

In Greece, most of the unions in our sample appear to share a more universalistic understanding of labour solidarity, that derives both from their political orientation as well as their focus on (working) class interests, and from the fact that employment precariousness and unemployment affect an increasing number of working people (Kanellopoulos 2013). Despite the deteriorating effects of the 2008 crisis on the Greek labour market, they generally consider that workers' awareness and consciousness has risen. As for Poland, although the country was unaffected by either the 2008 crisis or the so-called 2015 migrant 'crisis', the government used the framework of crisis to advance its deregulatory policies (Theiss et al. 2017). Our findings reveal how unions and labour organisations responded to the situation by broadening their scope of action to new groups of beneficiaries. Finally, in the case of the UK, our interviews revealed a willingness to view labour solidarity through a broader scope than the traditional forms of organising. Thus, some unions have taken active steps to widen access to their organisations and at the same time other, nonunion organisations have emerged and grown to meet the needs of these same communities and groups, diversifying the landscape of labour solidarity in the UK.

Although the challenges faced by unions and labour-oriented organisations have been similar in the three countries, we did not find robust evidence of a proper 
transnational scale of action among the activities of these organisations. But still, we did appreciate a capacity to read national economic situations and workers' fates as being part of common, larger, policy paradigm which could be better challenged by unifying forces across borders. From a rhetorical point of view, at least, the organisations we interviewed have identified the existence of a transnational workforce facing the same challenges and struggling for the recognition of the same rights. However, despite this transnational dimension these same workers have not yet appeared to be strong enough to push organisations towards more coordinated crossborder actions. In Greece, although the organisations' and unions' representatives recognise the importance of transnational labour solidarity, few organisations in our sample, share, at a practical level regular and well-established relations to unions and labour organisations abroad. This is also valid in the case of Poland, where even though our interviewees often spoke of the internationalism of working-class problems, the transnational actions of their organisations remain limited. As for the case of the UK, interviews also reveal some evidence of transnational solidarity via the scope of the organisation or the impact of the 2008 crisis on colleagues elsewhere. Nevertheless, despite clear motivation among some of our interviewees to retain their transnational connections, their activism takes place in a context where cross-border solidarity has come under intense pressure (one example being the process of the UK leaving the EU). We must of course consider that this may be a matter of scarce resources, given that transnational engagement requires human and financial resources, both of which have been curtailed in the labour movement over the last three decades, whether or not the organisations are traditional or 'new'.

Hence, the 2008 crisis, whether it was experienced through austerity policies, such as in Greece or the UK, or if it is a rhetorical device to advance labour market reform as seen in Poland, has brought some forms of organisational innovation in the field of workers' mobilisation. It has provided an opportunity to discuss solidarity in terms of who the beneficiaries of help should be, and where they should be located, whether at the local or at the transnational level. However, these discussions have not yet resulted in moving grassroots organisations' and unions' field of action to the global scale, where the forces of capital continue to shape our economies.

\section{References}

Chabanet D and Faniel J (2012) Introduction: The mobilization of the unemployed in a comparative perspective. In : Chabanet D and Faniel J (eds). The Mobilization of the Unemployed in Europe. New York : Palgrave Macmillan, pp. 1-27.

Department for Business, Energy and Industrial Strategy (2018) Trade union statistics 2017.

Faniel J (2012) Trade Unions and the Unemployed: Towards a Dialectical Approach. Interface 4(2): 130-157

Gumbrell-McCormick R and Hyman R (2015) International trade union solidarity and the impact of the crisis. European Policy Analysis 1: 1-16.

Hall, P. A., and Soskice, D. (Eds.). (2001). Varieties of Capitalism: The Institutional Foundations of Comparative Advantage. Oxford: Oxford University Press.

Heery E (2005) Sources of Change in Trade Unions. Work, Employment and Society 19 (1): $91-106$. 
Hyman R (2007) How can trade unions act strategically?. Transfer 13(2): 193-210.

Hyman R and Gumbrell-McCormick R (2017) Resisting labour market insecurity: old and new actors, rivals or allies?. Journal of Industrial Relations59(4): 538-561.

Kanellopoulos K. (2013) The remaking of the Greek working class, paper presented at the $10^{\text {th }}$ Annual Conference of Historical Materialism, SOAS, University of London, 7-10 November 2013, London, UK

Kanellopoulos K., Kostopoulos K., Papanikolopoulos D., Rongas V. (2017) Competing modes of coordination in the Greek anti-austerity campaign, 2010-2012. Social Movement Studies. 16(1): 101-118

Karakioulafi C (2019) Unions and Labour Solidarity: Pending between Inclusiveness and Exclusiveness - The Case of Greek Trade Unions. In Christodoulou M and Spyridakis M (eds). Emotions, Temporalities and Working-Class Identities in the 21st Century. New York : Nova Publishers, pp. 125-150.

Kretsos L and Vogiatzoglou M (2015) Lost in the Ocean of Deregulation? The Greek Labour Movement in a Time of Crisis. Industrial Relations70(2): 218-239.

Krzywdziński M (2012).Trade unions in Poland: Between stagnation and innovation. Management Revue 23 (1): 66-82.

Mattoni A and Vogiatzoglou M (2014) Italy and Greece, before and after the crisis: Between mobilization and resistance against precarity. Quaderni 84: 57-71.

Bithymitris, G and Kotsonopoulos L (2018) Transformation of the Greek trade union movement since the Metapolitefsi up until the crisis: continuities and ruptures. Greek review of Political Science 44: 99-122.

Martínez LM, Marino S. and Connolly H (2017) Organising as a strategy to reach precarious and marginalised workers. A review of debates on the role of the political dimension and the dilemmas of representation and solidarity. Transfer 23 (1): 31-46.

Milne S (2004) The enemy within: The secret war against the miners. London: Verso.

Mrozowicki A. and Trawińska M (2012) Women's union activism and trade union revitalization: The Polish experience. Economic and Industrial Democracy34 (2): 269-289.

Petelczyc J., Matuszczyk K. (2019)Zaangażowanie zwiąków zawodowych w Polsce w prawa okołopracownicze - perspektywa zwiąkowców, Polityka Społeczna, 46/3(540) pp. 20-24

Shin Y and Ylä-Anttila T (2017) New social risk groups, industrial relations regimes and union membership. Journal of European Social Policy 28 (3) :242-254

Simms M and Holgate J (2010) Organising for what? Where is the debate on the politics of organising?. Work, Employment and Society 24 (1): 157 - 168.

Theiss M., Kurowska A., Petelczyc J., Lewenstein B. (2017), Obywatel na zielonej wyspie. Polityka społeczna i obywatelstwo społeczne $w$ Polsce $w$ dobie europejskiego kryzysu ekonomicznego, IFIS PAN, Warszawa 2017

Visser J (2008) Industrial Relations in Europe 2009. Luxembourg: Office for Official Publications of the European Communities.

Vogiatzoglou M (2014) Trade Unions in Greece: Protest and Social Movements in the Context of Austerity Politics. WSI-Mitteilungen 5:361-368. 
Vogiatzoglou M (2015) Workers' transnational networks in times of austerity: Italy and Greece. Transfer 21 (2): 215-228.

\footnotetext{
${ }^{1}$ Our definition of solidarity is drawn from the common definition used in the TransSOL project from which this paper stems.

${ }^{2}$ Transnational labour solidarity can take the form of coordination of joint collective actions; the transfer of intraorganisational resources; collaboration, including mutual exchange of know-how, practices and resources (Vogiatzoglou, 2015). Some unions favour more institutionalised forms of solidarity while others prefer more activist-focused tactics and thus behave more like protest movements than interest groups.

${ }^{3}$ https://stats.oecd.org/Index.aspx?DataSetCode=TUD

${ }^{4}$ The post-dictatorship period is marked by attempts to shape a union identity with a strong class dimension, followed by the increase of labour militancy and workers' protest action. During the 1980's class identity gave way to a 'social democratic' identity, followed by a 'Europeanisation' period, where prevails an approach of social consent and the strengthening of unions' economic functions (Kanellopoulos 2013, Kanellopoulos et al 2017; Bithymitris and Kotsonopoulos 2018).

${ }^{5}$ https://unitetheunion.org/why-join/membership-types/community-membership/

${ }^{6}$ https://www.bbc.co.uk/news/uk-england-derbyshire-36855374

${ }^{7}$ http://www.betterthanzero.scot/

${ }^{8}$ Interviews complement two other forms of data used in the collaborative project from which this paper is derived (website coding and a standardised survey), by providing more illustrative and indepth insight into solidarity activities.

${ }^{9}$ Black, Asian and minority ethnic.
} 